\title{
8
}

\section{The semantics of verbs of visual aesthetic appreciation in Russian}

\author{
Anna Gladkova
}

\author{
Ty postoj, postoj, krasavica moja, \\ Daj mne nagljadet'sja, radost' na tebja. \\ 'Wait, wait, my beauty, \\ Let me feast my eyes on you, my joy!' \\ Russian folk song
}

\section{Introduction}

The lines of the Russian folk song chosen as an epigraph for this article contain an interesting Russian verb nagljadet'sja, which defies translation into English due to its language and culture specificity. Here, I chose to translate this verb as 'to feast one's eyes on' but true translational equivalence is not achieved. The chapter is devoted to the analysis of two Russian verbs expressing visual aesthetic appreciation: nagljadet'sja 'to look at someone/ something to complete satisfaction/feast one's eyes on' and ljubovat'sja 'to admire/feast one's eyes on', both defying translation into English. These verbs provide a key to understanding folk aesthetics (Gladkova and Romero-Trillo 2014, forthcoming(a), forthcoming(b)) because they capture the desire and longing for something through looking-the primary sense of appreciation of what is considered 'beautiful'. This study 
also contributes to the area of 'visual semantics' (e.g. Wierzbicka 2005; Apresjan 2018; Levisen 2019) where linguistic and cultural variation is at an early stage of exploration.

The study will use data from the Russian National Corpus and will aim to provide semantic explications of these words in semantic primes as they are represented in the Natural Semantic Metalanguage (NSM) developed by Anna Wierzbicka and Cliff Goddard (Goddard and Wierzbicka 2002, 2014). Anna Wierzbicka has applied NSM to the study of Russian language and culture in her numerous publications (Wierzbicka 1972, 1990, 1992, 1997, 1998, 2002, 2009, 2011, 2012, among others). This chapter to a significant extent builds on Wierzbicka's research in this area.

\section{The semantics of nagljadet'sja}

Nagljadet'sja belongs to a group of Russian verbs that share structural similarity (prefix $n a$-and reflexive suffix - sja) as well as the meaning 'to do something to the degree of complete satisfaction' (Švedova 1980). Some examples of other verbs belonging to this group are: napit'sja 'to drink enough', naest'sja 'to eat enough', nasluśat'sja 'to listen enough', naguljat'sja 'to walk enough', nakatat'sja 'to ride enough', naradovat'sja 'to rejoice enough', načitat'sja 'to read enough', naplakat'sja 'to cry/whip enough', nasmejat'sja 'to laugh enough', as well as others.

For nagljadet'sja, as well as other verbs in this group, it is difficult to identify equivalent verbs with exact meanings in English, which express completeness of an action as well as a degree of satisfaction on the part of the actor. Nagljadet'sja expresses satisfaction from looking at something. ${ }^{1}$ In this regard, it is notable that the verbs expressing 'seeing' or 'looking' fall within the same group of verbs as 'eating', 'drinking', 'walking', 'crying', 'laughing' and 'reading'. These verbs present activities that a person might want to do for existential need or pleasure and might want to do it for some time and achieve a degree of satisfaction from doing them. This fact emphasises the role of 'seeing' in human perception. Analysing it through

1 Along with nagljadet'sja there is another verb with similar meaning — nasmotret'sja. They share morphological structure (prefix $n a$ - and suffix -sja), but differ slightly stylistically due to the difference of root verbs they derive from: gljadet' and smotret', both translating into English as 'to look/see'. While the analysis of nasmotret'sja can be equally enlightening in terms of linguistic and cultural specificity of the semantics of visual aesthetics, we will ignore the analysis of nasmotret'sja due to space limit and focus on the meaning of nagljadet'sja. 
the prism of language-based 'folk aesthetics', one might get important insights and understandings relevant to this salient human function (cf. Itier and Batty 2009; Hansen and Ji 2010).

Nagljadet'sja, as suggested by the Russian Grammar (Švedova 1980), has the meaning 'to look at someone/something to the degree of complete satisfaction'. Interestingly, in actual use, the verb might have a slight variation in meaning depending on the structure and the context. Observations over corpus data suggest that when used in the past, the verb mainly refers to a negative experience and involves one looking at something to the degree that one does not want to do it anymore. Some contexts contain direct reference to some negative experience. In others, there is a hint of negativity that might be arising from the component of meaning implying satisfaction and not wanting to do it anymore. In this use, nagljadet'sja frequently collocates with adverbs expressing a high level of satisfaction: vvolju, vdostal', vdovol', all translating into English as (approximately) enough, in full or in plenty.

In certain contexts, the object or objects of observation and the associated emotions are clearly negative:

(1) Ljudi nagljadelis' na vsevozmožnye akty žestokosti, svireposti ... 'People have seen enough acts of cruelty and ferocity ...'

(2) Nagljadelis' v gorode vsjakoj grjazi, načitalis' knižek, vse uprostili i prišli, estestvenno, $\mathrm{k}$ vyvodu, čto nadobno stroit' novyj mir.

'[They] have seen all sorts of filth in the city, read books, simplified everything and consequently concluded that [they] need to build a new world.'

In numerous contexts the objects are not mentioned straightforwardly and involve words like mnogoe 'a lot', raznoe 'different things' and vse 'everything', thus indicating a great degree of experience, including both positive and negative, but mainly negative:

(3) Poživ v Moskve, ona, pravda, na mnogoe nagljadelas ...

'Having lived in Moscow she has seen a lot ...' 
(4) Oni oba dolgie gody proveli v stalinskix lagerjax i nagljadelis' mnogogo.

'They both spent many years in Stalin's camps and had seen a lot.'

(5) My ne sumasšedšie. My prosto vsego nagljadelis'.

'We are not mad. We simply have seen all sorts of things.'

(6) Vsego nagljadelas', ko vsemu privykla, daže k prestupnikam!

'[I] have seen everything, got used to everything, even to criminals!'

Certain contexts do not necessarily involve an evaluation, but there is a possible interpretation of the situation as negative:

(7) $\ldots$ on otslužil v armii, a zaodno i vdovol' nagljadelsja na kraski russkogo severa, poskol'ku načalas' ego služba v Komi, a zakončilas' pod Arxangel'skom ...

'.. he had served in the army and had seen the colours of the Russian North a lot as his service started in Komi and ended near Arkhangelsk ...'

The use that interests us most is the use of nagljadet'sja expressing a high degree of visual aesthetic appreciation. In this use, nagljadet'sja is used in constructions expressing modality:

dat' nagljadet'sja:

'let (someone) nagljadet'sja' (as in the song quoted in the epigraph)

ne moč nagljadetsja: 'can not nagljadet'sja'

ne nagljadet'sja: 'not nagljadet'sja' 'not be able to nagljadet'sja' nevozmožno nagljadet'sja: 'impossible to nagljadet'sja'

Let us consider some examples of such use from the corpus:

(8) ... pjat'desjat let ja každyj den' gljažu na Volgu i vse nagljadet'sja ne mogu.

'... I have been looking at the Volga for fifty years and cannot see enough of it.'

(9) Skol'ko ja ni smotrju na ètot pejzaž - ne mogu nagljadet'sja. 'No matter how much I look at this landscape, I can't see enough of it.' 
(10) Potrjasennyj, ja ne mog nagljadet'sja na otkryvšujusja vzoru krasoty. 'Stunned, I could not see enough of the beauty in front of my eyes.'

(11) Ona ljubit smotret' na nizkie oblaka - ne nagljadet'sja. 'She likes to look at low clouds; one can't see enough of them.'

(12) Ne toropis', vse budet. Daj xot' nagljadet'sja na tebja ...

'Don't be in a hurry, everything will happen. Let me at least look at you enough ...'

In the second use in modal frames, the verb tends to be used with people and landscape or creations of nature as objects. It can also be used with objects created by people. In all cases, these objects are characterised by some special beauty or they are of particular value to the observer. For example, as in example (12), the object of admiration is someone's dear relative or friend they haven't seen for a long time.

A close link between the action nagljadet'sja and one's close and dear people is well illustrated by its derivative nenagljadnyj (literally, 'someone that one cannot look enough at'). It is an adjectival form which means 'one's dear/ beloved person'. It is commonly used as an endearment form of addressmoj/moja nenagljadnyj(-aja) 'my dear/beloved'. This form fits well the value of warmth in interactions with close and dear people (Gladkova 2013a).

It is debatable whether there is enough justification to posit polysemy for nagljadet'sja. We would argue that despite the observed difference in use, it is unlikely that this difference is the case of polysemy (cf. Goddard 2009; Polguère 2018). Rather, we observe some different resonance due to the context and the tendency to occur in different structures. However, we will tentatively propose two different explications: one for the use in the past (as the invariant of meaning) and one in modal constructions.

The following explication ${ }^{2}$ can represent the invariant meaning of nagljadet'sja: ${ }^{3}$

2 Presumably, this explication, with the change of the prototype verb can be extended to other Russian verbs expressing an action performed to the degree of complete satisfaction.

3 The explications proposed in this chapter use the semantic universal SEE. It is also possible that in certain contexts it would be preferable to use to look as a semantics molecule to reflect the intentional element of the seeing process. The relationship between SEE and to look is complex and requires further investigation (see Padučeva (2004) on the relationship between the Russian equivalents of to see and to look). 


\title{
[A] $X$ nagljadelsja na $Y$ ' $X$ has seen enough of $Y$ '
}

\author{
a. someone $X$ saw someone/something $Y$ for a long time \\ b. someone $X$ saw someone/something $Y$ many times \\ c. because of this, after this, $X$ didn't want to see someone/something \\ $Y$ anymore
}

When referring to events in the past, nagljadet'sja emphasises the idea of sufficiency of the action of 'seeing'; it happens to the degree that one does not want to do it anymore. In many contexts, there is a shade of meaning of this action being unavoidable. However, it is unlikely that this component could be posited as part of meaning of the word; rather, it comes from the context.

For the use of nagljadet'sja in a modal frame we would propose the following explication:

\section{[B] $X$ ne mog nagljadet'sja na $Y$ ' $X$ couldn't look enough at $Y^{\prime}$}
a. someone $X$ saw someone/something $Y$ for a long time
b. someone $X$ saw someone/something $Y$ many times
c. someone $X$ wanted to see someone/something $Y$ more
because when someone $X$ sees someone/something $Y$, someone $X$ feels something very good
d. someone $X$ felt something very good when someone $X$ was doing it

This frame of use involves a prolonged process of looking at something or someone and also a desire to do it more. This desire is associated with inherent pleasure acquired from this process.

It might be illuminating to mention again morphological and structural similarity of nagljadet'sja with other Russian verbs, such as napit'sja 'to drink till satisfaction', naest'sja 'to eat till satisfaction', among others, which express actions that one wants to do till complete satisfaction. In this regard, seeing someone or something (usually for the sake of pleasure or satisfaction) is conceptualised as a kind of basic need along with eating or drinking. 


\section{The semantics of ljubovat'sja}

We will now turn to the analysis of another Russian verb expressing aesthetic admiration and appreciation: ljubovat'sja 'to admire/feast one's eyes on'. Etymologically it relates to the verb ljubit 'to like/love', therefore one can interpret its meaning as 'to like something by looking at it'. Jurij Apresjan describes ljubovat'sja as:

a controlled prolonged action, in the process of which the gaze can be gliding from one detail of the object to the other; this movement of the eyes can be accompanied by bending of the head, mimics, etc. (2004: 527)

Importantly, this process brings pleasure to the observer.

As it is the case with nagljadet'sja, ljubovat'sja defies translation into English. The English verb to admire, its closest equivalent, is broader in use. The expressions like I admire your sense of humour or I admire your strength would be more suitable to translate with the verb vosxiščat'sja. Also, to admire can extend to hearing and smell, while ljubovatsja is strictly limited to seeing. Another possible translation of ljubovat'sja- 'to feast one's eyes on'-is a metaphoric expression and has more limited use in English than ljubovat'sja does in Russian. The suggested difference in conceptualisation between the two languages emphasises the role of linguistic influence in the conceptualisation of senses and their relationship to aesthetic appreciation (Iordanskaja 1979; Wierzbicka 2010; Gladkova and Romero-Trillo 2014; see also Ye 2007). While this point requires further investigation, it is possible to hypothesise that Russian suggests a sharper distinction between 'senses' than English does and 'seeing' occupies a clearly 'leading' role among other ways of perception.

Ljubovat'sja is a process taking place over some time, it cannot be momentary. Looking at something or someone brings satisfaction to the person. The objects of ljubovat'sja can be quite diverse-people and parts of their bodies, elements of nature and landscapes, objects produced by people as well as people's actions. I will provide examples from the corpus to illustrate each of the uses:

Nature and landscape:

(13) Egor stal ljubovat'sja pejzažem.

'Egor was admiring the landscape.' 
(14) Paroxod otxodil tol'ko nočju, a ja, vzjav bilet, sel, ožidaja pribytija paroxoda, na vysokom beregu, ljubovalsja Volgoj, zaxodjaščim solncem, večernim nebom.

'The ship was leaving only in the evening; after buying the ticket I sat on the bank admiring the Volga, the sunset and the evening sky while waiting for the ship.'

(15) Ej vsego-to i hotelos' - ljubovat'sja krasivymi rastenijami, uxaživat' za nimi, trogat' inogda rukami i vdyxat' ix zapaxi ...

'All she wanted was to admire beautiful plants, look after them, sometimes touch them and inhale their smell ...'

People and parts of their body:

(16) I moej babuške bylo prijatno, vsjakoj materi prijatno, kogda ljubujutsja ee rebenkom.

'It was pleasing to my grandmother, like to any mother, when her child is being admired.'

(17) Stoja na beregu ručja, ja ljubovalsja djadej i ego lošad'ju.

'Standing on the bank of the creek I was admiring my uncle and his horse.'

(18) Ja dolgo ljubovalsja ego licom, krotkim i jasnym, kak večernee nebo. 'I was admiring his face for a long time, meek and clear like evening sky.'

(19) Každyj raz, kogda on prixodil, ja ljubovalsja na ego ruki.

'Every time he came I was admiring his hands.'

\section{People's actions:}

(20) Kogda byval v nastroenii i delal čto-to putnoe, na nego nel'zja bylo ne ljubovat'sja.

'When he was in good mood and did something worthwhile, it was impossible not to admire him.' 
(21) Ljubujas' dočer'ju, on smejalsja, gljadja, kak ona lovko laviruet meždu poklonnikami, ne podozrevajuščimi o suščestvovanii drug druga.

'Admiring his daughter he laughed seeing how skilfully she was manoeuvring between her admirers who did not suspect about the existence of each other.'

\section{Objects:}

(22) I posle obeda my ljubovalis' kovrami.

'After lunch we admired the carpets.'

(23) Takie 3D-kartiny pritjagivajut vzgljad, xočetsja postojanno ljubovat'sja imi, čtoby obresti duševnoe ravnovesie i spokojstvie.

'Such 3D pictures attract the eye; one want to constantly admire them in order to achieve spiritual balance and calm.'

Šmelev (2005a: 454) argues that ljubovat'sja occupies a special place in the Russian value system because, overall, the Russian language encodes a negative attitude to gaining and experiencing pleasure. However, ljubovat'sja is an exceptional type of pleasure that is encouraged by public opinion because it is a 'selfless' aesthetic pleasure. In this regard, Zalizniak and Šmelev (2004: 210) also note that ljubovat'sja would not be applicable to a person gaining pleasure from looking through a pornographic magazine.

Undoubtedly, ljubovat'sja is associated with positive value. It indicates pleasure derived from looking at something and implies beauty of the object. As a general cultural rule, ljubovat'sja is an accepted action. However, in the situation of gender relations, one might want to not demonstrate it openly because it signals one's admiration. Some contexts from the corpus point to that:

(24) Valentina Ivanovna daže slegka ustranilas' ot del i ljubovalas' so storony Ėdikom-Siloj.

'Valentina Ivanovna even briefly put aside her job to admire Edik from the side.'

(25) Ljudmila, otkrovenno ljubujas' nežnym rumjancem, prisuščim vsem ryžim ljudjam, ne otpuskala ego podborodka ...

'Ludmilla openly admiring the tender blush characteristic of all red-haired people, did not leave his chin ...' 
We will attempt the following explication of ljubovat'sja:

\section{[C] $X$ Ijubovalsja $Y$ 'person $X$ was admiring $Y$ '}

a. someone $X$ saw someone/something $Y$ for some time, not a short time

b. someone $\mathrm{X}$ wanted to do it

c. when someone $X$ was doing it, someone $\mathrm{X}$ wanted to see many parts of someone/something $Y$ someone $X$ wanted to see someone/something $Y$ well

d. when someone $X$ was doing it, someone $X$ couldn't not feel something very good

like people can't not feel something very good at some times when they see some things

e. someone $X$ thought something very good about someone/something $Y$

This explication captures that ljubovat'sja is a prolonged and intentional process (components a and b) which involves looking at the object in detail (component c). This process brings pleasure to the observer (component $\mathrm{d}$ ) that is akin to 'aesthetic' admiration and involves a positive evaluation of the object (component e).

In the semantics of both verbs it is interesting to observe an overlap with the meaning of krasivyj 'beautiful' (Gladkova and Romero-Trillo 2014; Gladkova forthcoming). Krasivyj implies an absolute characteristic. This quality is absolute in the sense that looking at the object should bring pleasure regardless of personal preferences of the observer. In Gladkova and Romero-Trillo (2014) the relevant component is formulated as 'this someone can't not feel something very good because of this, like people can't not feel something very good at some times when they see some things'. This component is explicit in the meaning of ljubovat'sja, thus making it a verb of aesthetic appreciation. This difference is blurred in the case of nagljadet'sja in the sense that this word denotes primarily personal pleasure derived from looking at someone or something that might or might not be 'beautiful'. 


\section{Discussion and conclusions}

This work presented the analysis of two Russian verbs of visual aesthetic appreciation-nagljadet'sja and ljubovat'sja. It demonstrated that nagljadet'sja involves looking at someone or something to the degree of complete satisfaction. We observe some difference in the use of the verb. In the past use, it mainly refers to a negative or neutral experience. Its use in the frame expressing modality is of particular interest to us, where it conveys a high degree of pleasure derived from looking at someone or something and the desire to continue doing it longer. Ljubovat'sja expresses a desired, controlled and concentrated action, which involves looking attentively at someone or something for some time. This process also brings pleasure and involves a positive evaluation of the object.

While there is no scope in this chapter for a full-fledged cross-cultural and cross-linguistic analysis that could bring light on cultural characteristics and diversity in this area, it is possible to make some observations about specificity of the lexicon in question and set a possible agenda for future research in the domain of aesthetics-related visual semantics.

To start with, it is possible to consider the semantics of the verbs in question against several Russian 'cultural themes', which have mainly been described by Wierzbicka.

First, the verbs of 'aesthetic appreciation' discussed in this chapter relate to the general theme of 'open' and 'sincere' expression of emotion. Wierzbicka (2002) formulates relevant scripts as follows:

[people think like this:]

it is good if a person wants to say to other people what this person thinks (feels)

it is bad if a person says to other people that this person thinks (feels) something if it is not true

it is good if a person wants other people to know what this person thinks (feels)

In some regard, the verbs in question denote a desire to look at someone/ something as a demonstration of a genuine and spontaneous positive attitude and this desire is openly shown as the conducted analysis suggests. 
Second, the role of 'desire' to look at someone or something for aesthetic pleasure is quite prominent in the semantics of the verbs in question. These elements of meaning can be associated with the theme of a 'strong' desire, discussed by Wierzbicka in relation to the role of gorjačij 'hot' in Russian conceptualisation of feelings and desires (Wierzbicka 2009). She formulates a relevant cultural script as follows (Wierzbicka 2009: 430):

[people think like this:]

it is good if someone can think like this about some things:

'something very good can happen

I want it to happen

I want it very much'

it is good if this someone feels something because of this

like people feel when they want something very much

Third, the analysis of these verbs makes it possible to relate their meanings to other Russian cultural themes. Primarily, it is a special role of human relations and warmth in interactions with close and dear people (Wierzbicka 1997, 2002; Gladkova 2010, 2013a, 2013b; Larina 2015; Larina et al. 2017). As it has been observed, the words under analysis might have close people as objects; that is, someone whom one wants to see for a long time. At the same time, the verb nagljadet'sja is an interesting example of encoding an action performed 'to the full' that correlates with the cultural theme of 'doing things to the full or extreme' (Šmelev 2005b).

Fourth, the Russian verbs can also be discussed in the light of the tendency of openly telling another person what would be good or not to do (Wierzbicka 2011, 2012). This could be interpreted as 'putting pressure' from the point of view of Anglo culture, but it does not have this implication in Russian. A request daj mne nagljadet'sja na tebja ('let me look enough at you') might sound imposing from an Anglo perspective. However, from the point of view of Russian culture, it does not have such implication because it is primarily interpreted in view of expressing positive feelings among close people.

It is also notable that the Russian verbs in question defy translation into English. This might suggest that aesthetic admiration and appreciation is an important cultural theme in Russian. It testifies itself in the fact that such kind of admiration can be expressed and is encouraged to be expressed. 
When it comes to exploring cultural diversity, it would be interesting to consider what standards of 'beauty' in terms of human body and clothes are, as well as nature (e.g. Bromhead 2011, 2018; Romero-Trillo and Espigares 2012; Lišaev 2015). This can lead us to the issue of cultural difference in the arena of non-verbal communication and different attitudes to gazing at someone or something for a prolonged time.

With a brief reference to possible English translational equivalents of the verbs in question, we could observe difference in the role of senses in aesthetic appreciation. The Russian verbs under analysis have a distinct reference to vision as a primary source of aesthetic pleasure. The difference in distinction and separation of senses for Russian and English has been observed earlier (Iordanskaja 1979; Wierzbicka 2010) and in particular in relation to aesthetic appreciation (Gladkova and Romero-Trillo 2014; Gladkova forthcoming). Russian seems to differentiate more distinctly than English does the role of senses in aesthetic appreciation, assigning 'seeing' a particularly prominent role. To put it differently, Russian associates aesthetic pleasure mainly with seeing and hearing, while in English this type of pleasure more easily extends to all senses. This indicates a further need of exploration of the field of aesthetics in relation to different senses.

Overall, the study supports the need for further investigation in the field of folk aesthetics and understanding how different languages conceptualise human aesthetic experience. The study of visual semantics and in particular aesthetics of visual semantics cannot be exhausted by the study of words as such, but it would require a development of cultural scripts and rules associated with appreciation of 'beautiful' and attitudes to 'ugly'. Tentatively, the data analysed in this chapter support the ideas expressed earlier in the literature (Levontina 2004; Zalizniak and Šmelev 2004; Šmelev 2005a) that aesthetic appreciation occupies a special role in the Russian linguistic world view and might suggest the existence of the following cultural script in Russian culture:

[many people think like this:]

it can be good if someone can't not feel something very good when this someone sees someone/something

like people can't not feel something very good when they see something it can be good if someone wants to see this someone/something for some time 


\section{References}

Apresjan, Jurij (2004). Ljubovat'sja, zagljadet'sja. In Jurji Apresjan, (ed.), Novyj ob"jasnitel'nyj slovar' sinonimov russkogo jazyka [The New Explanatory Dictionary of Russian Synonyms]. Moskva-Wien: Jazyki slavjanskoj kul'turyWiener Slawistischer Almanach, 526-29.

Apresjan, Valentina (2018). Russian constructions with syntactic reduplication of color terms: A corpus study. Russian Journal of Linguistics 22 (3): 653-74. doi.org/10.22363/2312-9182-2018-22-3-653-674.

Bromhead, Helen (2011). The bush in Australian English. Australian Journal of Linguistics 31 (4): 445-71.

Bromhead, Helen (2018). Landscape and Culture - Cross-linguistic Perspectives. Amsterdam: John Benjamins.

Gladkova, Anna (2010). Russkaja kul'turnaja semantika: émocii, cennosti, žiznennye ustanovki [Russian Cultural Semantics: Emotions, Values, Attitudes]. Moscow: Languages of Slavonic Cultures [in Russian].

Gladkova, Anna (2013a). 'Intimate' talk in Russian: Human relationships and folk psychotherapy. Australian Journal of Linguistics 33 (3): 322-43. doi.org/ 10.1080/07268602.2013.846453.

Gladkova, Anna (2013b). 'Is he one of ours?' The cultural semantics and ethnopragmatics of social categories in Russian. Journal of Pragmatics 55: 180-94. doi.org/10.1016/j.pragma.2013.06.010.

Gladkova, Anna (forthcoming). What is beauty? Cultural semantics of the Russian folk aesthetics. International Journal of Language and Culture.

Gladkova, Anna and Jesus Romero-Trillo (2014). Ain't it beautiful? The conceptualization of beauty from an ethnopragmatic perspective. Journal of Pragmatics 60: 140-59. doi.org/10.1016/j.pragma.2013.11.005.

Gladkova, Anna and Jesus Romero-Trillo (forthcoming(a)). The linguistic conceptualization in folk aesthetics. International Journal of Language and Culture.

Gladkova, Anna and Jesus Romero-Trillo (eds) (forthcoming(b)). Special issue, "'Beautiful" and "ugly" across languages and cultures'. International Journal of Language and Culture.

Goddard, Cliff (2009). Polysemy. A problem of definition. In Yael Ravil and Claudia Leacock (eds), Polysemy: Theoretical and Computational Approaches. Oxford: Oxford University Press, 129-51. 
Goddard, Cliff and Anna Wierzbicka (eds) (2002). Meaning and Universal Grammar: Theory and Empirical Findings (2 vol.). Amsterdam: John Benjamins.

Goddard, Cliff and Anna Wierzbicka (2014). Words and Meanings: Lexical Semantics Across Domains, Languages and Cultures. Oxford: Oxford University Press. doi.org/10.1093/acprof:oso/9780199668434.001.0001.

Hansen, Dan Witzer and Qiang Ji (2010). In the eye of the beholder: A survey of models for eyes and gaze. IEEE Transactions on Pattern Analysis and Machine Intelligence 32 (3): 478-500. doi.org/10.1109/TPAMI.2009.30.

Iordanskaja, Lidia (1979). O semantike russkix glagolov: vosprinimat', oščuščat' i čuvstvovat' [On the semantics of the Russian verbs vosprinimat', oščuščat' and čuvstvovat']. Wiener Slawistischer Almanach 3: 207-17.

Itier, Roxane and Magali Batty (2009). Neural bases of eye and gaze processing: The core of social cognition. Neuroscience \& Biobehavioral Reviews 33 (6): 843-63. doi.org/10.1016/j.neubiorev.2009.02.004.

Larina, Tatiana (2015). Culture-specific communicative styles as a framework for interpreting linguistic and cultural idiosyncrasies. International Review of Pragmatics 7 (5): 195-215. doi.org/10.1163/18773109-00702003.

Larina, Tatiana, Arto Mustajoki and Ekaterina Protassova (2017). Dimensions of Russian culture and mind. In Katja Lehtisaari and Arto Mustajoki (eds), Philosophical and Cultural Interpretations of Russian Modernisation. London/ New York: Routledge, 7-19.

Levisen, Carsten (2019). 'Brightness' in color linguistics: New light from Danish visual semantics. In Ida Raffaelli, Daniela Katunar and Barbara Kerovec (eds), Lexicalization Patterns in Color Naming: A Cross-Linguistic Perspective. Amsterdam: John Benjamins, 83-105. doi.org/10.1075/sfsl.78.05lev.

Levontina, Irina (2004). Ostorožno, pošlost'! [Beware of vulgarity]. In Nina D. Arutjunova (ed.), Logičeskij analiz jazyka. Jazyki èstetiki. Konceptual'nye polja prekrasnogo i bezobraznogo [Logical Analysis of Language. Languages of Aesthetics. Conceptual Fields of Beautiful and Ugly]. Moscow: Indrik, 231-50 [in Russian].

Lišaev, Sergej (2015). Aestetika prostranstva [The Aesthetics of Space]. St Petersburg: Aleteya.

Padučeva, Elena. (2004). Dinamičeskie modeli v semantike leksiki [Dynamic Models in the Semantics of Lexicon]. Moscow: Jazyki slavjanskoj kul'tury [in Russian]. 
Polguère, Alain (2018). A lexicographic approach to the study of copolysemy relations. Russian Journal of Linguistics 22 (4): 788-820. doi.org/10.22363/ 2312-9182-2018-22-4-788-820.

Romero-Trillo, Jesus and Tescar Espigares (2012). The cognitive representation of natural landscapes in language. Pragmatics and Cognition 20: 168-85. doi.org/ $10.1075 /$ pc.20.1.07rom.

Šmelev, Alexey (2004). Vidy aestetičeskoj ocenki v predstavlenii russkogo jazyka [Types of aesthetic evaluation in Russian]. In Nina D. Arutjunova (ed.), Logičeskij analiz jazyka. Jazyki estetiki. Konceptual'nye polja prekrasnogo i bezobraznogo [Logical Analysis of Language. Languages of Aesthetics. Conceptual Fields of Beautiful and Ugly]. Moscow: Indrik, 303-11 [in Russian].

Šmelev, Alexey (2005a). Skvoznye motivy russkoj jazykovoj kartiny mira [Central motifs of the Russian linguistic world view]. In A. Zalizniak, I. Levontina and A. Šmelev (eds), Ključevye idei russkoj jazykovoj kartiny mira [Key Ideas of the Russian Linguistic World View]. Moskow: Jazyki slavjanskoj kul'tury, 452-64 [in Russian].

Šmelev, Alexey (2005b). Širota russkoj duši [The breadth of the Russian soul]. In A. Zalizniak, I. Levontina and A. Šmelev (eds), Ključevye idei russkoj jazykovoj kartiny mira [Key Ideas of the Russian Linguistic World View]. Moskow: Jazyki slavjanskoj kul'tury, 51-63 [in Russian].

Švedova, N. (ed.) (1980). Russkaja grammatika [Russian Grammar] (2 vols). Moscow: Nauka [in Russian].

Wierzbicka, Anna (1972). Semantic Primitives. Frankfurt: Athenäum.

Wierzbicka, Anna (1990). Duša ('soul'), toska ('yearning'), sud'ba ('fate'): Three key concepts in Russian language and Russian culture. In Zygmunt Saloni (ed.), Metody formalne w opisie jezyków stowianskich [Formal Methods in the Description of Slavic Languages]. Bialystok University Press, 13-36.

Wierzbicka, Anna (1992). Semantics, Culture, and Cognition: Universal Human Concepts in Culture-Specific Configurations. New York: Oxford University Press.

Wierzbicka, Anna (1997). Understanding Cultures through their Key Words: English, Russian, Polish, German, and Japanese. New York: Oxford University Press.

Wierzbicka, Anna (1998). Russian emotional expression. Ethos 26 (4): 456-83.

Wierzbicka, Anna (2002). Russian cultural scripts: The theory of cultural scripts and its applications. Ethos 30 (4): 401-32. doi.org/10.1525/eth.2002.30. 4.401 . 
Wierzbicka, Anna (2005). There are no 'color universals' but there are universals of visual semantics. Anthropological Linguistics 47 (2): 217-44.

Wierzbicka, Anna (2009). Pragmatics and cultural values: The hot centre of Russian discourse. In Bruce Fraser and Ken Turner (eds), Language in Life, and a Life in Language: Jacob Mey - A Festschrift. Bingley: Emerald, 423-34. doi.org/10.1163/9789004253209_055.

Wierzbicka, Anna (2010). Experience, Evidence, and Sense: The Hidden Cultural Legacy of English. New York: Oxford University Press. doi.org/10.1093/ acprof:oso/9780195368000.001.0001.

Wierzbicka, Anna (2011). Arguing in Russian: Why Solzhenitsyn's fictional arguments defy translation. Russian Journal of Communication 4 (1/2): 8-37. doi.org/10.1080/19409419.2011.10756788.

Wierzbicka, Anna (2012). 'Advice' in English and in Russian: A contrastive and cross-cultural perspective. In Holger Limberg and Miriam A. Locher (eds), Advice in Discourse. Amsterdam: John Benjamins, 309-32.

Ye, Zhengdao (2007). Taste as a gateway to Chinese cognition. In Andrea C. Schalley and Drew Khlentzos (eds), Mental States: Volume 2: Language and Cognitive Structure. Amsterdam: John Benjamins, 109-32.

Zalizniak, Anna A. and Alexey D. Šmelev (2004). Éstetičeskoe izmerenie v russkoj jazykovoj kartine mira: byt, pošlost', vran'e [Aesthetic dimension in the Russian linguistic worldview: byt, pošlost', vran'e]. In Nina D. Arutjunova (ed.), Logičeskij analiz jazyka. Jazyki èstetiki. Konceptual'nye polja prekrasnogo $i$ bezobraznogo [Logical Analysis of Language. Languages of Aesthetics. Conceptual Fields of Beautiful and Ugly]. Moscow: Indrik, 209-30 [in Russian]. 
This text is taken from Meaning, Life and Culture: In conversation with Anna Wierzbicka, edited by Helen Bromhead and Zhengdao Ye, published 2020 by ANU Press, The Australian National University,

Canberra, Australia.

doi.org/10.22459/MLC.2020.08 